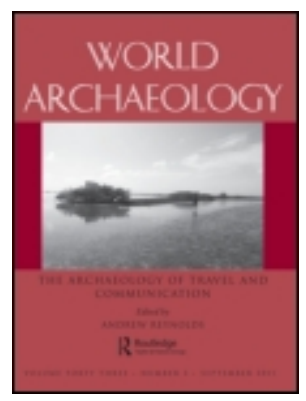

\title{
Genetics, archaeology and the far right: an unholy Trinity
}

\begin{tabular}{|r|l|}
\hline Journal: & World Archaeology \\
\hline Manuscript ID & RWAR-2018-0063.R1 \\
\hline Manuscript Type: & Original Papers \\
\hline Date Submitted by the \\
Author: & n/a \\
\hline Complete List of Authors: & $\begin{array}{l}\text { Hakenbeck, Susanne; University of Cambridge, Department of } \\
\text { Archaeology; }\end{array}$ \\
\hline Keywords: & archaeogenetics, culture history, migration, Far Right \\
\hline &
\end{tabular}

SCHOLARONE

Manuscripts 
1 Genetics, archaeology and the far right: an unholy Trinity

2 Susanne E. Hakenbeck

3 Department of Archaeology, Downing Street, University of Cambridge, Cambridge CB2 3DZ

4 seh43@cam.ac.uk

5 ORCID: https://orcid.org/0000-0003-2409-0146

6 Word count: 5694

7

8 


\section{Genetics, archaeology and the far right: an unholy Trinity}

2

3

4

5

6

7

8

9

Recent advances in archeogenetics have revived an interest in grand narratives in which ethnic groups are once again thought to be agents of historical change. New scientific developments are generating a sense of optimism that difficult questions in palaeodemography may at last be solved. However, genetic research often uncritically makes use of essentialist models of past populations, reifying genetic populations as ethnic groups. This paper explores how such views of the past may play into notions of racial purity and fears of non-European migrants stoked by adherents of far-right ideologies.

Keywords: archaeogenetics; culture history; migration; Far Right

\section{Introduction}

In June 2015, two papers were published that seemed to transform our understanding of the population history of Europe. Wolfgang Haak et al. (2015) and Morten Allentoft et al. (2015) undertook genomic analyses of 69 and 101 individuals, respectively, spanning a period of 5000 years, from 8000 to 3000 years ago. The studies showed a massive demographic change between 4500 and 3000 years ago when an earlier ancestral group which was described as a mixture of European hunter-gatherers and Near Eastern farmers was almost fully replaced by a third ancestral group deriving from the Eurasian steppe belt. This third ancestral group has been identified with the so-called Yamnaya culture characterised by distinctive burial practices (Allentoft et al. 2015, 167). The people who created this Yamnaya culture appear to have been engaged in nomadic-pastoralism. People associated with the late Neolithic Corded Ware culture subsequently traced 79 per cent of their ancestry to the Yamnaya (Haak et al. $2015,210)$. Such massive demographic change has been linked to the plague, but also to the colonisation of western Europe by predatory males (Rasmussen et al. 2015; Kristiansen et al. 2017, 339). 
1 These studies have had great significance, not only because they provide a further

2 dimension to our knowledge of the population history of Europe, but also because they re-

3 ignited an old debate about the origin of the Indo-European language family. The so-called

4 kurgan culture of the Bronze Age steppes north of the Caucasus was first proposed as the

5 homeland of proto-Indo-European (PIE) speakers by Marija Gimbutas $(1965,23)$.

6 Gimbutas's hypothesis was later countered by Colin Renfrew $(1987,159 ; 1992)$ who argued

7 that the spread of Indo-European languages was linked to the dispersal of agriculture in

8 Europe and that the origin of PIE therefore lay in Anatolia 9000 to 8000 years ago.

9 Nevertheless, the hypothesis of Bronze Age language dispersal from the steppes retained

10 currency; principally promoted by David Anthony $(2013 ; 2007,83)$. The new genetic studies

11 appeared to give strong support to the steppic origin of PIE. In one fell swoop two significant

12 problems in the population history of Europe appeared to have been solved: where did the

13 peoples of Europe come from? And where did their languages come from?

14 These, and other related studies of genomic population history, generated great

15 enthusiasm among some archaeologists and geneticists about the possibilities now offered by

16 ancient DNA studies to archaeological research (Der Sarkissian et al. 2015; Kristiansen 2014;

17 Kristiansen et al. 2017; Anthony and Brown 2017). In a discussion article in Current Swedish

18 Archaeology which stimulated spirited responses Kristian Kristiansen calls these

19 developments the 'third science revolution' in archaeology, which, he claims, follows the

20 systematising work of the mid-nineteenth century and the radiocarbon revolution of the mid-

21 twentieth century (Kristiansen 2014, 14). He suggests that the new methods will have a

22 transformational impact not only by generating new evidence about the past, but - crucially -

23 also by changing how we study and think about the past. He states that "we are in a period of

24 theoretical and methodological experimentation and reorientations, where everything that was

25 "forbidden" research 10-15 years ago are now among the hottest themes: mobility, migration, 
1 warfare, comparative analysis, evolution, and the return of grand narratives' (Kristiansen

$22014,14)$. He considers these changes to be part of 'a larger shift from postmodernity to a

3 revised modernity' (Kristiansen 2014, 23). In the face of such exuberant optimism, it is worth

4 looking in more detail at what Kristiansen might mean by such a reorientation.

\section{Migrations}

Migration is one of the areas of 'forbidden' research mentioned by Kristiansen and it

7 serves as a useful prism for tracking changes in archaeological thought over time. Throughout

8 the nineteenth and early twentieth centuries, scholars had assumed that achievements of

9 civilisation had spread westwards from the Near East and Egypt either through the diffusion

10 of ideas or with the migration of people (Trigger 1997, 148; Adams, Von Gerven, and Levy

11 1978, 487). The primary method by which such migrations were traced in prehistory, and

12 indeed in historic periods too, was by tracing the movement of 'cultures' or 'culture groups'

13 (Childe 1925, 1950). Crucially, this notion of archaeological cultures assumes that ethnic

14 groups are uncomplicated categories, clearly bounded and with a material record that is

15 uniquely distinctive to them. The movement of these material attributes then becomes a proxy

16 for the movement of people.

17 In British archaeology, the dominant perspective up to the 1960s was that all cultural

18 innovations had come to the British Isles from continental Europe, either through the

19 movement of people or through the diffusion of ideas. This was so universally accepted that

20 Grahame Clark diagnosed British archaeologists in 1966 with an invasion neurosis,

21 suggesting that 'they went out of their way to ascribe every good thing about their early past

22 to foreign influences, if not indeed to foreign conquerors' (Clark 1966, 173).

23 The major theoretical critiques of the 1960s and again in the 1980s completely

24 overturned this and shifted the focus towards local developments, initially from an

25 evolutionary perspective and later with a turn towards theoretical approaches that 
1 foregrounded local and small-scale developments and which focused on identities over

2 externally ascribed ethnic identifiers. Migration was largely rejected as an explanatory device

3 (Adams, Von Gerven, and Levy 1978, 503). Instead, social change was explained primarily

4 with indigenous developments and, more specifically, with the notion that shifting ideas and

5 identities bring about change in material culture. These approaches have latterly been

6 criticised as 'local, 'indigenist"” or "immobilist" theorizing' (Hawkes 1987, 203; Chapman

7 and Hamerow 1997, 1).

When Kristiansen speaks of a coming paradigm shift in archaeology, in the wake of

9 new scientific advances, and of a shift from 'postmodernity to a revised modernity', he means

10 a turn away from these 'immobilist' approaches. However, he also implies a turn away from

11 the notion that the subject and his or her subjective experiences of identity have primacy over

12 external material signs of ethnicity or over genetic attributes of ancestry. Scientific

13 approaches seem now to provide certainty and clarity in the formerly confused mixture of

14 people and things. Yet, does this really herald a new way of thinking about the past? A closer

15 look at the assumptions inherent in many genomic studies should raise doubts. The paper by

16 Allentoft et al. (2015) was the more extensive of the two studies, involving a sample of 101

17 individuals across Eurasia, spanning a date range of about 3000 years and a distance from east to west of about 5000 kilometres (3000 miles). Samples were chosen to represent different archaeological cultures, the clusters still matching Gordon Childe's map of early 20 Bronze Age cultures from 1925 very well (Childe 1925, 343) (Fig. 1). The genetic samples 21 teeth from specific individuals picked out from cemeteries - stand in for entire archaeological 22 cultures which, in turn, represent ethnic groups. The implication of this sampling 23 methodology is that each individual is representative of their ethnic group. There is no 24 consideration of the particular social, economic and environmental contexts of the burials, 25 nor of multiple ways by which social factors might influence population structure. 
Work since 2015 has focused on the nature and process of these migrations into western Europe. A study of Y-chromosome sequences, for example, noted an expansion of male lineages in Europe that coincided with the origin of the Yamnaya culture and two other significant archaeological cultures (Corded Ware and Bell-Beaker cultures) (Poznik et al. 2016, 597). Choosing selectively to focus on this evidence over other studies that detected evidence for high levels of female mobility and patrilocality, Kristiansen et al. $(2017,339)$ interpreted this pattern as being caused by war-bands of young men who migrated from the steppes to marry, or perhaps abduct, local women (contra Knipper et al. 2017; Sjögren, Price, and Kristiansen 2016).

They based this interpretation on work undertaken by scholars of Indo-European linguistics. Drawing on words and texts from the vast corpus of Indo-European languages, these scholars paint a picture of groups of roving, predatory young men that were thought to be a part of the social organisation of all Indo-European societies, from the earliest PIEspeakers to the Vrātyas of the Indian subcontinent and such groups among early medieval populations (Kershaw 2000; Petrosyan 2011). The assumption is that all societies sharing Indo-European languages must therefore also share a common social organisation.

Rather than being a dawn of new ways of thinking about the past, this is a throw-back to archaeological and linguistic methods of the early twentieth century, by-passing developments that have led to a more critical and nuanced way of thinking about ethnicity, gender and migrations. Instead, we see a return to notions of bounded ethnic groups equivalent to archaeological cultures and of a shared Indo-European social organisation based on common linguistic fragments. Both angles are essentialist and carry a deeply problematic ideological baggage. We are being offered an appealingly simple narrative of a past shaped by virile young men going out to conquer a continent, given apparent legitimacy by the scientific method. 


\section{Archaeology, genetics and the public}

The results of these studies were disseminated to news media through university press

3 releases ("When modern Eurasia was born" 2015; "A massive migration from the steppe

4 brought Indo-European languages to Europe" 2015). The publications on the genetic impact

5 of the Yamnaya culture were picked up enthusiastically, with headlines particularly focusing

6 on a narrative of migrations and the origins of Europeans (e.g. Jakobsen 2015; Griffiths and

7 Newton 2015; "Wir sind Erben der Steppenreiter" 2015). Similarly, the highly gendered

8 elements of the subsequent papers was directly promoted by the scholars in a press release

9 and reworked into exciting headlines by journalists (Liberatore 2017; "Steppe migrant thugs

10 pacified by Stone Age farming women" 2017). In a recent story in the New Scientist,

11 Kristian Kristiansen again emphasised the apparently violent impact of the Yamnaya: "II've

12 become increasingly convinced there must have been a kind of genocide," says Kristian

13 Kristiansen at the University of Gothenburg, Sweden (Barras 2019)'.

14 It is therefore not surprising that far-right and white supremacist groups also can be traced back to the racial anthropology of the nineteenth century and to the eugenics movement (Levine 2010; Marks 2012). The increasing commercial availability of genomic ancestry tests over the last decade have reignited this interest, making it possible for members of these groups to examine their own whiteness genetically. While these tests have at times had destabilising effects on white nationalists' notions of their own racial identity, there is

21 nevertheless a widespread consensus that race is a genetic reality. Sociologists Aaron nationalists with genetics on the webforum Stormfront. This forum has existed since 1995 when it was launched by a former Grand Wizard of the Ku Klux Klan, Don Black. It receives several million page views per month (Panofsky and Donovan 2017, 13). Due to its size, it 
1 provides a useful sounding board for discussions about race and genetics among white

2 supremacists online. Panofsky's and Donovan's study revealed a preoccupation with

3 population history, especially in the context of the results of forum users' own genetic

4 ancestry tests.

5

6

7

My own examination of discussion threads on Stormfront revealed that the main interest of members was in Y-chromosome haplotypes that they believe to identify the white race. However, there were also 250 mentions of 'Yamnaya', 346 of 'Corded Ware' and 87 of 'Bell Beakers' (last accessed on 2 April 2019). A number of these make direct reference to recent genomic studies. In a thread entitled 'West-Europeans not the original IndoEuropeans' forum members discussed the results of the studies by Haak et al. (2015) and Allentoft et al. (2015). User PolishSlavAryan came to the conclusion that the Yamnaya culture represented the Aryans they were looking for as the ancestors of Europeans. Another user, Everdred, writes: 'A primarily male migration of Yamnaya herders westward into Central and Northern Europe took up wives from the Neolithic farming cultures and gradually formed the new Corded Ware Culture, which likely represented the ProtoGermanic community (Thread: New study on the formation of Corded Ware Culture; 04-062017, 05:29 AM)'.

Responding rapidly to a story in the New Scientist ('Story of the most murderous people of all time revealed in ancient DNA', 27 March 2019) the same user comments, using anti-semitic code: 'Looks like $(((\square))$ and others are starting an "academic" attempt to demonize the Yamnaya (Proto-Indo-Europeans) as evil, genocidal maniacs.' (Thread: Archaeology; 31-03-2019, 10:22 pm; redacted by author).

The great number of links to scientific publications and media reports of research on the Stormfront forum indicates that genomic research on population history are of great appeal to some members of racist and far-right groups since they believe that this research 
1 will reveal objectively the origins of races. News reports on the Yamnaya are of particular

2 interest since they seem to be providing clues to the origins of Aryans.

The gendered elements of the research, especially the focus on male war-bands, also resonate with masculine self-conceptions on many far-right websites. The Aryan

Männerbund was promoted by the Nazis to be part of the natural order of German society and can be found again in modern fascist movements (Gottschewski 1934; Baeumler 1934;

Weiser-Aall 1927). Over the course of the twentieth century far-right men in Scandinavia,

8 Germany and the US have enduringly identified themselves with the ideal of the warrior

9 hero, banded together in militias (Miller-Idriss 2017; Michael 2003).

\section{Migrations and grand historical narratives}

White nationalists do not exist in a social vacuum and their notions about race and migrations are extreme re-imaginings of widely shared popular ideas. The widespread use of commercial genetic ancestry testing has led to a 'racialization of genetics and the molecularization of race', according to Aaron Panofsky and Catherine Bliss $(2017,80)$, caused in part by geneticists' frequent use of race- or geography-based population labelling in their studies which is in turn replicated by commercial companies. Catherine Nash $(2015,81)$ notes that population geneticists often hold the prior assumption 'that sociocultural categories such as ethnic identities correspond with genetic distinctiveness'. While the impact of such tests on personal identities may be variable (Scully, Brown, and King 2016), we can nevertheless detect a broader social consensus that there is indeed a genetic basis to many common-sense conceptions of population difference. This ties in with a current popular concern with migration, brought on partly by the European refugee crisis beginning in 2014,

23 but also more widely by the global labour-migrations of the last decades. News stories

24 involving past migrations generate significant interest and these are invariably framed in ethnic terms. The infamous 'Breaking Point' poster of the Vote Leave campaign in front of 
1 which the British far-right politician Nigel Farage was photographed in June 2016, just weeks

2 before the Brexit referendum in the UK, illustrates the clearly racial dimensions of this. Scholars working on genomic population histories have so far not engaged enough with the wider social context in which their work is received. The histories of archaeology and anthropology are intertwined with the histories of nationalism, colonialism and racism, and much important research has revealed past political appropriations of our disciplines (e.g. Trigger 1984; Alfredo 2010; Gould 1996; Kohl and Fawcett 1995; Beck et al. 2004), but there is a danger that this is considered a problem of the past that has been overcome. While there is a lively scholarly debate both about the implication of the results of genomic studies and about research methods and assumptions, this has largely been confined to scholars in the field (Hofmann 2015; Furholt 2017; Vander Linden 2016; Vander Linden 2018; Heyd 2017; "Forum: Genetic History" 2018). However, geneticists and archaeologists also need to consider the outward-facing consequences of their genomic studies more critically.

\section{Nomenclature and sampling practices: top-down or bottom-up?}

What is to be done? There are two areas where more work is needed. First, the research methodology of genomic studies must fully consider the complexities surrounding ethnicity and migration that are coming out of theoretically-informed research in archaeology, and it must do so before data collection, not after (Niklasson 2014, 59). A central problem here is that biological populations are often implicitly assumed to be congruent with ethnic groups. In a survey of archaeogenomic publications since 2014, Stefanie Eisenmann et al. (2018) examined the nomenclature used to describe the relationship between genetic clusters and archaeological evidence. They found that only one publication (Fu et al. 2016) used an entirely neutral nomenclature, i.e. by simply naming genetic clusters based on the name of the site from where the samples were taken. All others used labels 
1 based on subsistence strategies (e.g. hunter-gatherers) or archaeological cultures (e.g. Corded

2 Ware), or a combination of both. The authors are of the opinion that the use of such labels

3 nevertheless has value, since 'convergences [between genetic clusters and archaeological

4 cultures] might help shed light on the nature of an archaeological culture, how it spread, and

5 what may lie hidden behind a group of similar objects and/or practices.' (Eisenmann et al. $62018,8)$.

Perhaps, but this sidesteps a more fundamental methodological problem. Taking small

8 numbers of samples of individuals as representative of social or culture groups introduces an

9 a priori assumption that social or culture groups must be genetically homogeneous and it

10 obscures any genetic heterogeneity that may be present. That this may be the case has already

11 been observed in some cases (Olalde et al. 2018; Gamba et al. 2014). To counter simplistic

12 notions of migration, Marc Vander Linden (2019) has called for explicit hypothesis testing

13 through a series of demographic simulations that would allow us to determine the most likely

14 causes of genetic admixture or replacement.

15 Instead of presupposing that genetic ancestry and patterns in material culture must

16 overlap, we should therefore ask ourselves, do burial identity, ancestry and migration form a

17 coherent package? If not, what does this mean for the past societies that we study? A number

18 of fine-grained genomic studies of individual cemetery populations are beginning to provide

19 fascinating insights here (Amorim et al. 2018; Knipper et al. 2017; Schiffels et al. 2016).

20 Krishna Veeramah $(2018,87)$ rightly calls for the need for a 'bottom up' approach to

21 genomic sampling as the only way that will allow us to understand past social processes such 22 as migrations.

\section{Communicating with the public}


2 processes by which it is communicated to the public may further problematic political and

3 social agendas. Journalists and popular authors are beginning to show the way. Two recent

4 books written for a more general audience have tried to emphasise the complexity of human

5 ancestry and have also referred to the dangers of racist interpretations of genomic data (Bojs

6 2017, 340; Reich 2018, 247). In an article in the New York Times Magazine, Gideon Lewis

7 Kraus drew attention to the complex web of personal relationships, laboratory infrastructures,

8 sampling strategies and journals' peer review practices that characterises contemporary

9 archaeogenetics and which may facilitate researchers' emphasising exciting stories over

10 nuance (Lewis-Kraus 2019).

11 Yet, such critical reflection should not be left to outside observers. Archaeologists and

12 geneticists need to do the intellectual work themselves. We have to be more aware of the

13 public impact of our work, but, more importantly, we should also make efforts to shape the

14 public discourse ourselves.

Press releases are the main route by which academics can disseminate their work to the media. University press offices generally work closely with academics to make sure that the text is both scientifically accurate and engaging for a journalistic audience, since journalists often quote directly from the releases or rewrite them only in a minor way. Press releases are therefore key to shaping how research news is presented in the media. Rather than aiming to tell a simple, exciting story about ethnic groups and migrations, there is great value in being transparent about the complexities and difficulties that scholars encounter when they go about their work and there many are examples that show that such news stories can be just as engaging (e.g. Greshko 2017; Ward 2017).

This is particularly important in cases where research results are controversial or easily slotted into a Far Right or racist discourse. The demographics of Roman Britain have 
1 been one such area of controversy. In July 2017, an educational video produced by the BBC

2 which showed a brown-skinned centurion generated an intense (and sometimes vicious)

3 discussion on Twitter, with many contributors questioning the genetic and archaeological

4 evidence for such ethnic diversity in Roman Britain. Subsequently, a number of academics

5 contributed in nuanced and informative ways to the public debate, explaining the scientific

6 methods and countering misinformation (e.g. Raff 2017; Redfern 2018).

Public engagement can and should go beyond simply generating scientific news content. As researchers we should be transparent about the complexities of the research

9 process and the limits of our interpretations, but we should also aim to intervene critically in 10 public debates and to respond proactively when our research is used for problematic political 11 and ideological ends.

\section{Conclusion}

14 Scientific advances in sequencing ancient DNA over the last decade have opened up

15 new areas of research. It is now possible to create genomic population maps for different

16 periods in the human past and to discover information about past populations that was

17 previously entirely inaccessible to us. However, much of genomic research so far has

18 employed assumptions about past populations as static bounded units, characterised by

19 distinct material culture. These assumptions have much more in common with conceptual

20 approaches in the archaeology of the early twentieth century than of the early twenty-first. As

21 a result, the past few years have seen a reification of race and ethnicity under the banner of

22 scientific progress, and this has been communicated to a public already very interested in

23 narratives about origins and ancestry. Notions of a biological basis of race have also been

24 taken up enthusiastically by white supremacists interested in the ancestry of the 'white race'.

25 Recent genomic research on population histories has therefore provided scientific 
1 legitimation of pre-existing racialized and even racist ideas. There is little evidence that

2 scholars engaged in genomic research are trying to communicate the complexity of their

3 work; instead exciting but simplistic narratives abound. There is an urgent need for much

4 more critical rigour in genomic population studies, both in terms of the kinds of questions

5 that are being asked and in terms of how results are being communicated to the public.

6

7 Acknowledgements

8 I would like to thank David Redhouse for producing the illustration for this article. I am grateful to

9 Marc Vander Linden for his encouragement and numerous discussions of the topic, and to Doris

10 Gutsmiedl-Schümann, Philipp von Rummel and James Harland for their critical comments on a draft.

12 Figure 1. Sampling locations and classification according to period and/or archaeological 13 culture from the study by Allentoft et al. (2015: 168) superimposed on Gordon Childe's map 14 in Dawn of European Civilization (1925: 343-4).

15 Childe's legend: 'Europe in period IV c. 1400 B.C.: I Minoan-Mycenaean civilization; II 16 Civilization of Troy VI.; VII Perjámos culture; VIII Unětician culture; IX Glina III culture; X 17 Pontic Copper Age; XII Northern culture; XIIa Globular amphorae; XIII Siculan II culture; 18 XIV Terremare and allied cultures; XV El Agrar culture; XVI Mondsee-Altheim culture; 19 XVIII Armorican Bronze Age; XVIII Wessex culture; XIX Food-vessel culture; Battle-axe 20 cultures: E Boat-axe, F Separate grave, G Oder.' 21 


\section{Bibliography}

Adams, William Y., Dennis P. Von Gerven, and Richard S. Levy. 1978. "The retreat from migrationism." Annual Review of Anthropology 7:483-532.

Alfredo, González-Ruibal. 2010. "Colonialism and European archaeology." In Handbook of Postcolonial Archaeology, edited by Jane Lydon and Uzma Z. Rizvi, 39-50. London: Routledge.

Allentoft, Morten E., Martin Sikora, Karl-Goran Sjogren, Simon Rasmussen, Morten Rasmussen, Jesper Stenderup, Peter B. Damgaard, et al. 2015. "Population genomics of Bronze Age Eurasia." Nature 522 (7555):167-72. doi: 10.1038/nature14507.

Amorim, Carlos Eduardo G., Stefania Vai, Cosimo Posth, Alessandra Modi, István Koncz, Susanne Hakenbeck, Maria Cristina La Rocca, et al. 2018. "Understanding 6th-century barbarian social organization and migration through paleogenomics." Nature Communications 9 (1):3547. doi: 10.1038/s41467-018-06024-4.

Anthony, David W. 2007. The horse, the wheel, and language: how bronze-age riders from the Eurasian steppes shaped the modern world. Princeton, N.J.: Princeton University Press.

- - - 2013. "Two IE phylogenies, three PIE migrations, and four kinds of steppe pastoralism." Journal of Language Relationship 9:1-12.

Anthony, David W., and Dorcas R Brown. 2017. "Molecular archaeology and Indo-European linguistics: impressions from new data." In Usque ad Radices: Indo-European studies in honour of Birgit Anette Olsen, edited by Bjarne S. S. Hansen, Adam Hyllested, Anders Richart Jørgensen, Guus Kroonen, Jenny Helena Larsson, Benedicte Nielsen Whitehead, Thomas Olander and Tobias Mosbæk Søbord, 25-54. Copenhagen: Museum Tusculanum Press. Baeumler, Alfred 1934. Männerbund und Wissenschaft. Berlin: Junker und Dünnhaupt Verlag.

Barras, Colin. 2019. "Story of most murderous people of all time revealed in ancient DNA." New Scientist, 27 March 2019.

Beck, Heinrich, Dieter Geuenich, Heiko Steuer, and Dietrich Hakelberg. 2004. "Zur Geschichte der Gleichung "germanisch-deutsch"." In. Berlin and New York: Walter de Gruyter.

Bojs, Karin. 2017. My European family: the first 54, 000 years. London: Bloomsbury Sigma.

Chapman, John, and Helena Hamerow. 1997. "Introduction: On the move again - migrations and invasions in archaeological explanation." In Migration and Invasion in Archaeological Explanation, edited by John Chapman and Helena Hamerow, 1-9. Oxford: Archaeopress.

Childe, Vere Gordon. 1925. The Dawn of European Civilization. London: Kegan Paul.

- - . 1950. Prehistoric Migrations in Europe, Instituttet for Sammenlignende Kulturforskning. Serie A: Forlesninger). Oslo: $\mathrm{H}$. Aschehoug \& Co.

Clark, Grahame. 1966. "The invasion hypothesis in British archaeology." Antiquity 40 (159):172-89. doi: $10.1017 /$ S0003598X00032488.

Der Sarkissian, Clio, Morten E. Allentoft, María C. Ávila-Arcos, Ross Barnett, Paula F. Campos, Enrico Cappellini, Luca Ermini, et al. 2015. "Ancient genomics." Philosophical Transactions of the Royal Society B: Biological Sciences 370 (1660). doi: 10.1098/rstb.2013.0387.

Eisenmann, Stefanie, Eszter Bánffy, Peter van Dommelen, Kerstin P. Hofmann, Joseph Maran, losif Lazaridis, Alissa Mittnik, et al. 2018. "Reconciling material cultures in archaeology with genetic data: The nomenclature of clusters emerging from archaeogenomic analysis." Scientific Reports 8 (1):13003. doi: 10.1038/s41598-018-31123-z.

"Forum: Genetic History." 2018. NTM Zeitschrift für Geschichte der Wissenschaften, Technik und Medizin 26 (3):301-50. doi: 10.1007/s00048-018-0196-9.

Fu, Qiaomei, Cosimo Posth, Mateja Hajdinjak, Martin Petr, Swapan Mallick, Daniel Fernandes, Anja Furtwängler, et al. 2016. "The genetic history of Ice Age Europe." Nature 534:200. doi: 10.1038/nature17993

https://www.nature.com/articles/nature17993\#supplementary-information. 
Furholt, Martin. 2017. "Massive migrations? The impact of recent aDNA studies on our view of third millennium Europe." European Journal of Archaeology:1-33. doi: 10.1017/eaa.2017.43.

Gamba, Cristina, Eppie R. Jones, Matthew D. Teasdale, Russell L. McLaughlin, Gloria Gonzalez-Fortes, Valeria Mattiangeli, László Domboróczki, et al. 2014. "Genome flux and stasis in a five millennium transect of European prehistory." Nature Communications 5:5257. doi: $10.1038 /$ ncomms6257

https://www.nature.com/articles/ncomms6257\#supplementary-information.

Gimbutas, Marija Alseikaitè. 1965. Bronze Age Cultures in Central and Eastern Europe. The Hague: Mouton.

Gottschewski, Lydia. 1934. Männerbund und Frauenfrage. Die Frau im neuen Staat. München: J.F. Lehmanns Verlag.

Gould, Stephen Jay. 1996. The Mismeasure of Man. New York and London: W.W. Norton.

Greshko, Michael. 2017. "Famous Viking Warrior Was a Woman, DNA Reveals." National Geographic, 12 September 2017. https://news.nationalgeographic.com/2017/09/viking-warrior-womanarchaeology-spd/

Griffiths, Sarah, and Jennifer Newton. 2015. "Modern Europe was formed by milk-drinking Russians: Mass migration brought new genetic make-up to continent 5,000 years ago." Mail Online, June 11. https://www.dailymail.co.uk/news/article-3119310/How-white-Europeans-arrived5-000-years-ago-Mass-migration-southern-Russia-brought-new-technology-dairy-farmingcontinent.html

Haak, Wolfgang, losif Lazaridis, Nick Patterson, Nadin Rohland, Swapan Mallick, Bastien Llamas, Guido Brandt, et al. 2015. "Massive migration from the steppe was a source for IndoEuropean languages in Europe." Nature 522:207. doi: 10.1038/nature14317.

Hawkes, Christopher. 1987. "Archaeologists and Indo-Europeanists: can they mate?" In Proto-IndoEuropean: The Archaeology of a Linguistic Problem. Studies in Honor of Marija Gimbutas, edited by S.N. Skomal and E.C. Polomé, 203-15. Washington D.C.: Institute for the Study of Man.

Heyd, Volker. 2017. "Kossinna's smile." Antiquity 91 (356):348-59. doi: 10.15184/aqy.2017.21.

Hofmann, Daniela. 2015. "What have genetics ever done for us? The implications of aDNA data for interpreting identity in Early Neolithic Central Europe." European Journal of Archaeology 18 (3):454-76. doi: 10.1179/1461957114Y.0000000083.

Jakobsen, Rasmus Kragh 2015. "History rewritten: Europeans were "born" in the Bronze Age." Science Nordic, June 14. http://sciencenordic.com/history-rewritten-europeans-were\%E2\%80\%9Cborn\%E2\%80\%9D-bronze-age

Kershaw, Priscilla K. 2000. The one-eyed god: Odin and the (Indo-)Germanic Männerbünde. Washington, D.C.: Journal of Indo-European Studies.

Knipper, Corina, Alissa Mittnik, Ken Massy, Catharina Kociumaka, Isil Kucukkalipci, Michael Maus, Fabian Wittenborn, et al. 2017. "Female exogamy and gene pool diversification at the transition from the Final Neolithic to the Early Bronze Age in central Europe." Proceedings of the National Academy of Sciences 114 (38):10083-8. doi: 10.1073/pnas.1706355114.

Kohl, Philip L., and Clare Fawcett. 1995. "Nationalism, Politics, and the Practice of Archaeology." In. Cambridge: Cambridge University Press.

Kristiansen, Kristian. 2014. "Towards a new paradigm? The Third Science Revolution and its Possible Consequences in Archaeology." Current Swedish Archaeology 22:11-34.

Kristiansen, Kristian, Morten E. Allentoft, Karin M. Frei, Rune Iversen, Niels N. Johannsen, Guus Kroonen, Łukasz Pospieszny, et al. 2017. "Re-theorising mobility and the formation of culture and language among the Corded Ware Culture in Europe." Antiquity 91 (356):334-47. doi: 10.15184/aqy.2017.17.

Levine, Philippa. 2010. "Anthropology, Colonialism, and Eugenics." In The Oxford Handbook of the History of Eugenics edited by Alison Bashford and Philippa Levine, 44-62. Oxford: Oxford University Press. 
Lewis-Kraus, Gideon. 2019. "Is Ancient DNA Research Revealing New Truths — or Falling Into Old Traps?" New York Times Magazine, 17 January 2019.

https://www.nytimes.com/2019/01/17/magazine/ancient-dna-paleogenomics.html

Liberatore, Stacey. 2017. "How Stone Age farming women tamed nomadic warriors to give rise to the Corded Ware culture." Mail Online, April 5. https://www.dailymail.co.uk/sciencetech/article-4380874/How-Stone-Age-farming-womentamed-migrant-warriors.html

Marks, Jonathan. 2012. "The Origins of Anthropological Genetics." Current Anthropology 53 (S5):S161-S72. doi: 10.1086/662333.

"A massive migration from the steppe brought Indo-European languages to Europe." In. 2015. Jena: Max Planck Institute for the Science of Human History.

Michael, S. Kimmel. 2003. "Globalization and its Mal(e)Contents: The Gendered Moral and Political Economy of Terrorism." International Sociology 18 (3):603-20. doi: $10.1177 / 02685809030183008$.

Miller-Idriss, Cynthia. 2017. "Soldier, sailor, rebel, rule-breaker: masculinity and the body in the German far right." Gender and Education 29 (2):199-215. doi: 10.1080/09540253.2016.1274381.

Nash, Catherine. 2015. Genetic geographies: the trouble with ancestry. Minneapolis, Minnesota: University Of Minnesota Press.

Niklasson, Elisabeth. 2014. "Shutting the stable door after the horse has bolted." Current Swedish Archaeology 22:57-63.

Olalde, Iñigo, Selina Brace, Morten E. Allentoft, Ian Armit, Kristian Kristiansen, Thomas Booth, Nadin Rohland, et al. 2018. "The Beaker phenomenon and the genomic transformation of northwest Europe." Nature 555:190. doi: 10.1038/nature25738

https://www.nature.com/articles/nature25738\#supplementary-information.

Panofsky, Aaron, and Catherine Bliss. 2017. "Ambiguity and scientific authority: population classification in genomic science." American Sociological Review 82 (1):59-87. doi: $10.1177 / 0003122416685812$.

Panofsky, Aaron, and Joan Donovan. 2017. "When Genetics Challenges a Racist's Identity: Genetic Ancestry Testing Among White Nationalists." In SocArXiv.

Petrosyan, Armen. 2011. "Armenian Traditional Black Youths: the Earliest Sources." Journal of IndoEuropean Studies 39 (3):342-54.

Poznik, G. David, Yali Xue, Fernando L. Mendez, Thomas F. Willems, Andrea Massaia, Melissa A. Wilson Sayres, Qasim Ayub, et al. 2016. "Punctuated bursts in human male demography inferred from 1,244 worldwide Y-chromosome sequences." Nature Genetics 48:593. doi: 10.1038/ng.3559.

Raff, Jennifer. 2017. "If Mary Beard is right, what's happened to the DNA of Africans from Roman Britain? ." Guardian, 9 August 2017. https://www.theguardian.com/science/2017/aug/09/ifafricans-were-in-roman-britain-why-dont-we-see-their-dna-today-mary-beard

Rasmussen, Simon, Morten Erik Allentoft, Kasper Nielsen, Ludovic Orlando, Martin Sikora, KarlGöran Sjögren, Anders Gorm Pedersen, et al. 2015. "Early Divergent Strains of Yersinia pestis in Eurasia 5,000 Years Ago." Cell 163 (3):571-82. doi: 10.1016/j.cell.2015.10.009.

Redfern, Rebecca. 2018. "The Roman dead: new techniques are revealing just how diverse Roman Britain was " The Conversation, 24 May 2018. https://theconversation.com/the-romandead-new-techniques-are-revealing-just-how-diverse-roman-britain-was95243?utm campaign=meetedgar\&utm medium=social\&utm source=meetedgar.com\&fbcl id=IwAR0LvO1FPx5mz8coiZ wS-Y4Y4AKh6eDKZZCrJ3VepIrsAznOunn5Cdnu10

Reich, David. 2018. Who we are and how we got here: ancient DNA and the new science of the human past. Oxford: Oxford University Press.

Renfrew, Colin. 1987. Archaeology and Language: the Puzzle of Indo-European Origins. London: Jonathan Cape. 
- - . 1992. "Archaeology, genetics and linguistic diversity." Man (New Series) 27:445-78.

Schiffels, Stephan, Wolfgang Haak, Pirita Paajanen, Bastien Llamas, Elizabeth Popescu, Louise Loe, Rachel Clarke, et al. 2016. "Iron Age and Anglo-Saxon genomes from East England reveal British migration history." Nature Communications 7:10408. doi: 10.1038/ncomms10408.

Scully, Marc, Steven D. Brown, and Turi King. 2016. "Becoming a Viking: DNA testing, genetic ancestry and placeholder identity." Ethnic and Racial Studies 39 (2):162-80. doi: 10.1080/01419870.2016.1105991.

Sjögren, Karl-Göran, T. Douglas Price, and Kristian Kristiansen. 2016. "Diet and Mobility in the Corded Ware of Central Europe." PLOS ONE 11 (5):e0155083. doi: 10.1371/journal.pone.0155083.

"Steppe migrant thugs pacified by Stone Age farming women." 2017. Centre for Geogenetics, 4 April 2017. Accessed 24 October. https://geogenetics.ku.dk/latestnews/alle_nyheder/2017/steppe-migrant-thugs-pacified-by-stone-age-farming-women/.

"Stormfront - White Nationalist Community." Accessed 24 October 2018. https://www.stormfront.org/forum/index.php/.

Trigger, Bruce G. 1984. "Alternative archaeologies: nationalist, colonialist, imperialist." Man 19 (3):355-70.

Trigger, Bruce G. 1997. A history of archaeological thought. 8th ed. Cambridge: Cambridge University Press.

Vander Linden, Marc. 2016. "Population history in third-millennium-BC Europe: assessing the contribution of genetics." World Archaeology:1-15. doi: 10.1080/00438243.2016.1209124.

- - . 2019. "Toward a clearer view into human prehistory." Science 363 (6432):1153-4. doi: 10.1126/science.aaw8020.

Vander Linden, Marc 2018. "David Reich's Who We Are and How We Got Here: Ancient DNA and the New Science of the Human Past." Current Anthropology 59 (5):657-8. doi: 10.1086/699989.

Veeramah, Krishna R. 2018. "The importance of fine-scale studies for integrating paleogenomics and archaeology." Current Opinion in Genetics \& Development 53:83-9. doi: https://doi.org/10.1016/j.gde.2018.07.007.

Ward, Victoria. 2017. "Forget the wandering warrior: Bronze Age women travelled the world while men stayed at home " The Daily Telegraph, 4 September 2017. https://www.telegraph.co.uk/news/2017/09/04/forget-wandering-warrior-bronze-agewomen-travelled-world-men/

Weiser-Aall, Lily. 1927. Altgermanische Jünglingsweihen und Männerbünde: Ein Beitrag zur deutschen und nordischen Altertums- und Volkskunde. Bühl (Baden): Konkordia.

"When modern Eurasia was born." In. 2015. Copenhagen: Centre for Geogenetics, Natural History Museum.

"Wir sind Erben der Steppenreiter." 2015. scinexx.de, June 11. http://www.scinexx.de/wissenaktuell-18956-2015-0611.html?utm source=feedburner\&utm medium=feed\&utm campaign=Feed $\% 3 \mathrm{~A}+$ scinexx + \%28scinexx+\%7C+Das+Wissensmagazin\%29 


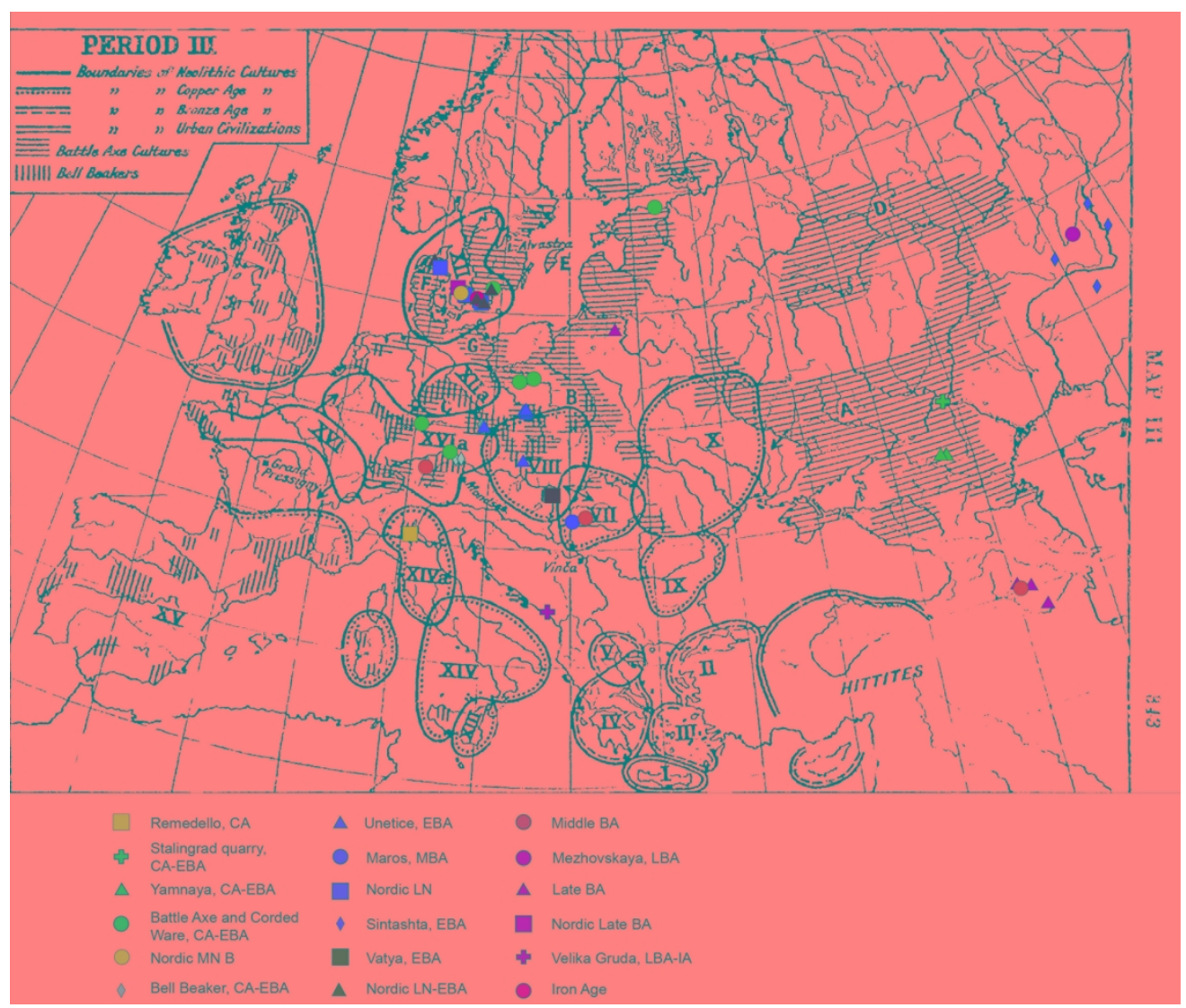

Figure 1. Sampling locations and classification according to period and/or archaeological culture from the study by Allentoft et al. (2015: 168) superimposed on Gordon Childe's map in Dawn of European Civilization (1925: 343-4).

Childe's legend: 'Europe in period IV c. 1400 B.C.: I Minoan-Mycenaean civilization; II Civilization of Troy VI.; VII Perjámos culture; VIII Unětician culture; IX Glina III culture; X Pontic Copper Age; XII Northern culture; XIIa Globular amphorae; XIII Siculan II culture; XIV Terremare and allied cultures; XV El Agrar culture; XVI Mondsee-Altheim culture; XVIII Armorican Bronze Age; XVIII Wessex culture; XIX Food-vessel culture; Battle-axe cultures: E Boat-axe, F Separate grave, G Oder.' 


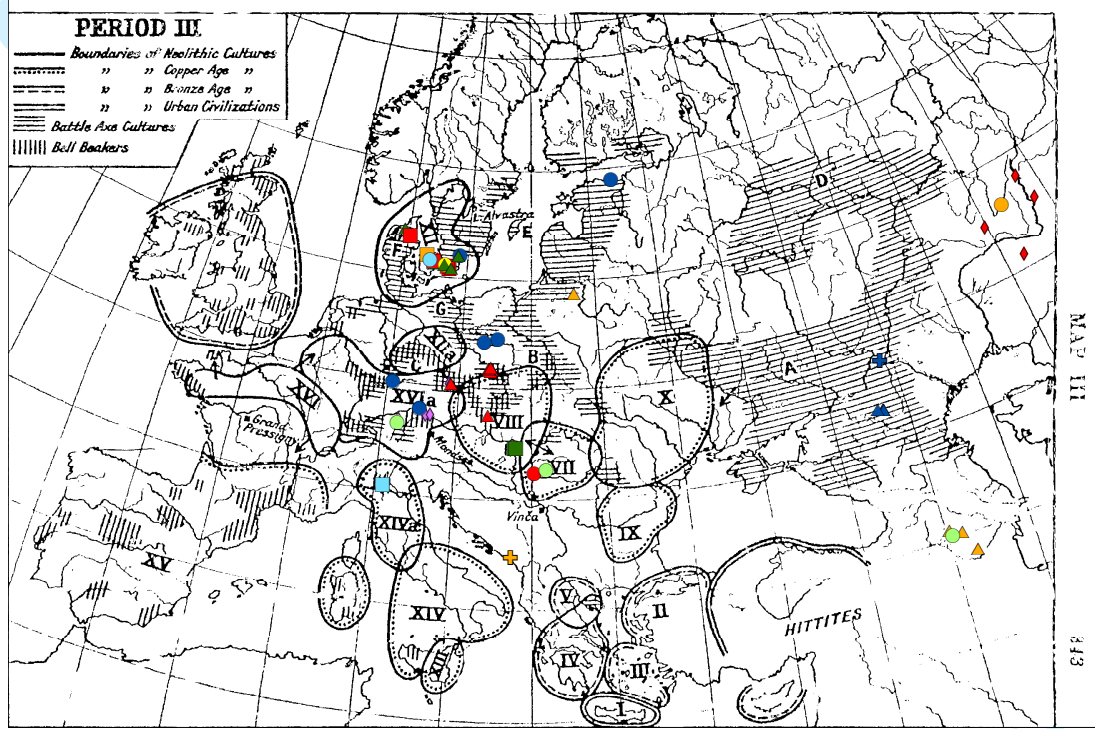
$\square \quad$ Remedello, CA
$\Delta$ Unetice, EBA
Middle BA
s. Stalingrad quarry,
O Maros, MBA
Mezhovskaya, LBA
$\Delta$ Yamnaya, CA-EBA
$\square$ Nordic LN
$\triangle$ Late BA

$\square$ Vatya, EBA

f) Velika Gruda, LBA-IA 